\title{
Palynological analysis of Dennstaedtiaceae taxa from the Paranaense Phytogeographic Province that produce Trilete spores II: Microlepia speluncae and Pteridium arachnoideum
}

\author{
AGUSTINA YAÑEZ, GONZALO J. MARQUEZ and MARTAA. MORBELLI \\ Cátedra de Palinología, Facultad de Ciencias Naturales y Museo, Universidad Nacional \\ de La Plata, Calle 64 N³, La Plata, Buenos Aires, Argentina
}

Manuscript received on April 9, 2015; accepted for publication on June 22, 2015

\begin{abstract}
The spore morphology and wall ultrastructure of Microlepia speluncae and Pteridium arachnoideum from the Paranaense Province were analyzed with LM, SEM and TEM and a comparative analysis was carried out. In both species the spores are covered by a three-dimensional network of threads branched and fused, tangentially arranged to the surface, and some free-end threads are also seen. The species were differentiated by morphology and the frequency of threads fusion and the networks distribution on the surface of the spores. In both species the exospore is two-layered in section, both layers are traversed by single or branched channels. The perispore is three-layered in section: the inner layer is adhered to the exospore, the middle layer is formed of a three-dimensional network of threads and the outer layer is discontinuous. The perispore ultrastructure of Microlepia speluncae was interpreted as formed of helical subunits displayed around a central channel. The spore morphology and perispore ultrastructure allow differentiating Microlepia from Pteridium but also to the other Dennstaedtiaceae genera that grow in the Paranaense Province. The results obtained allow establishing relationships that let us recognize different groups and gave a new reference to get a better knowledge of the family.
\end{abstract}

Key words: Spores, ultrastructure, Dennstaedtiaceae, Paranaense Province, Microlepia speluncae, Pteridium arachnoideum.

\section{INTRODUCTION}

This paper is part of the palynological study for Dennstaedtiaceae family growing in the Paranaense Phytogeographic Province (Cabrera and Willink 1973), also known as Paraná Forest Province and Araucaria Forest Province (Morrone 2001a, b, 2014). Up to the present, have been published the results of Dennstaedtia genus (Yañez et al. 2011);

Correspondence to: Agustina Yañez

E-mail: yanez_agustina@hotmail.com and genus Blotiella, Histiopteris and Paesia are currently under study.

Dennstaedtiaceae Bernh. family has about 170 species growing in pantropical, boreal or temperate regions (Smith et al. 2006). The genera assigned to the family, show wide morphological variability in the sporophyte and spores, as there are species producing spores monolete and the other trilete ones. Microlepia C. Presland Pteridium Gled ex Scop. are among the last ones, these being two broadly distributed taxa. 
Within the Paranaense Phytogeographic Province, Microlepia speluncae (L.) T. Moore is distributed mainly in Eastern Paraguay and SE Brazil, in the Brazilian states of Minas Gerais, Rio de Janeiro, São Paulo and Santa Catarina. Pteridium arachnoideum (Kaulf.) Maxon is also present in Paraná, Rio Grande do Sul, and NE Argentina (Ponce et al. 2008, Schwartsburd 2010, Anton and Zuloaga 2014).

Microlepia is a genus with 46 taxa, most of its species growing in tropical and warm-temperate Asian Pacific Ocean areas. Only one species, Microlepia speluncae, is present both in the Old World and in America, being broadly distributed and therefore, Tryon and Tryon (1982) suggested the taxon's adventitious nature and claimed that the species shows local variations. It has sorus with half cup-shaped indusium, basal and laterally attached to the lamina, slightly withdrawn from the margin (Kramer and Green 1990).

Pteridium is distinguished from Microlepia by having continuous marginal sorus, protected by an abaxial membranaceous indusium and by the recurved foliar margin. It is a cosmopolitan taxon, broadly distributed in tropical and temperate areas worldwide(Tryon and Tryon 1982). This distribution rank is due to the fact that most Pteridium species are considered weeds and colonize open spaces, generally as a consequence of anthropic activities, due to the fast growth of its extensive and resistant branched rhizomes (Den-Ouden 2000), as well as the great spore production, dispersing easily with the wind and germinating in short periods of time (Conway 1949, 1957). As a consequence of its broad distribution, poorly stable diagnostic features, population phenotype plasticity, and the existence of intermediate morphotype, there are several views on the taxa classification within Pteridium. While some authors describe it as a monotypic genus with several varieties (Tryon 1941, Cooper-Driver 1976, Van Cotthem 1970, Taylor 1990), others have acknowledged several species (Thomson and Alonso-Amelot 2002, Thomson 2004, 2012, Thomson et al. 2005, 2008). In the present work we follow the classification scheme used by Der et al. (2009), based on phylogenetic and biogeographical studies. The authors acknowledge two species in South America: Pteridium caudatum (L.) Maxon and Pteridium arachnoideum, and only the latter is present in the Paranaense Province (Sehnem 1972, Mickel and Smith 2004, Prado 2004, Assis and Salino 2011).

Pteridium and Microlepia palynology have been scarcely studied and most of the available research is restricted to optical microscopy analysis. The first authors to analyze the spores Microlepia taxa with LM described their ornamentations as psilate, granular, tubercled, banded (Knox 1938, Erdtman 1957), verrucate (Tardieu-Blot 1966) or echinulate (Selling 1946). Furthermore, the last author observed granular sculptured spores in Pteridium while Harris (1955) distinguished a scabrated or irregularly subgranular exospore.

Later, Nayar and Devi (1968a, b) studied the spores of the Pteridaceae family sensu Copeland (1947) and analyzed Pteridium aquilinum and 13 Microlepia species. In the first case, the authors defined a granular exine with rugulated coalescent granules, and the presence of an occasionally cracking fine outer layer. In Microlepia, they observed a smooth or densely granular exospore coinciding with that described by Devi (1977), Soepadmo and Khoo (1977), and Welman (1970). This last author indicated the presence of a granular perispore both in Pteridium aquilinum as well as in Microlepia speluncae, while Erdtman and Sorsa (1971), and Large and Braggins (1991) only informed by Pteridium. On the contrary, Huang (1981) identified the presence of perispore in Microlepia which he described as striate, reticulate, granular, psilate or scabrate.

There are few studies with electronic microscopy in both genera. In Pteridium aquilinum, Lugardon $(1971,1974)$ observed a "blechnoide" 
exospore type with attenuated ornamentation and a perispore with granular or lump-textured vertical expansions, without any defined shape. Later, Tryon and Tryon (1982) described the perispore of this species as granular with mass fused or short rod-like particles. The last authors described the M. speluncae perispore with thin rods or threads conforming an echinulate pattern and indicated the presence of a rod or thread grid under the perispore ornamented layer in both species. On the contrary, Tryon and Lugardon (1991) distinguished an inner granulated layer only for Microlepia.

Up to the present Microlepia speluncae spores have been scarcely studied for South America (Tryon and Tryon 1982, Tryon and Lugardon 1991, Graf-Meier 1985). Graf-Meier (1985) studied Pteridium arachnoideum spores (under P. aquilinum) with LM. Furthermore, South American species of Pteridium were studied with SEM in some local palynological flora (Lorscheitter et al. 2002, Contreras-Duarte et al. 2006, Giudice et al. 2006) as well as in morphologic studies on gametophyte (Ramírez-Trejo et al. 2013).

The purpose of this work is to make a comparative analysis of the Microlepia speluncae and Pteridium arachnoideum spore morphology of the Paranaense Province with LM, SEM, and TEM, in order to determine the ornamentation types present in these taxa and to establishing their relation respect to with stratification and wall ultrastructure. The results obtained will allow to compare these species with other Dennstaedtiaceae taxa and to establish relationships that would allow to circumscribe the family better. Finally, the intention is to contribute with the analysis of the reproductive structures present in the Pteridium species in order to generate controlling tools to this species.

\section{MATERIALS AND METHODS}

Spores from herbarium specimens were obtained from Museo Argentino de Ciencias Naturales
Bernardino Rivadavia, Buenos Aires, Argentina (BA); Instituto de Botánica del Nordeste, Corrientes, Argentina (CTES); Herbarium Bradeanum, Rio de Janeiro, Brazil (HB); Museo de Ciencias Naturales de La Plata, La Plata, Argentina (LP); Missouri Botanical Garden. Missouri, Saint Louis, USA (MO); Instituto de Botanica Darwinion, San Isidro, Argentina (SI); Instituto de Botânica, São Paulo, Brazil (SP) and Universidade Federal do Paraná, Curitiba, Brazil (UPCB). As the material from the Phytogeographical Paranaense Province was not enough, additional material from the Atlantic Province was studied (Cabrera and Willink 1973).

The spores were studied by using Light Microscope (LM), Scanning Electron Microscope (SEM) and Transmission Electron Microscope (TEM). For LM the spores were embedded in glycerine-jelly without any chemical treatment, since the perispore does not resist acetolysis treatment (Erdtman 1960). On the basis of measurements ( 25 spores for each sample) we obtained values of polar diameter, mayor equatorial diameter, minor equatorial diameter, and exospore and perispore thickness. Photographs were taken with Nikon Coolpix S10 digital camera.

For SEM the spores were treated with hot 3\% sodium carbonate, washed, dehydrated, suspended in $96 \%$ ethanol and then transferred to acetate plates (Morbelli 1980). After drying, they were coated with gold.

For TEM, dry material from herbarium specimens was hydrated following the technique proposed by Rowley and Nilsson (1972), that consist on the use of a buffer plus alcian blue (AB); then, the material was fixed with $1 \%$ glutalaldehyde (GA) $+1 \% \mathrm{AB}$ in phosphate buffer for $12 \mathrm{~h}$, and postfixed with $1 \%$ OsO4 in water plus $1 \% \mathrm{AB}$.

The spores were dehydrated in an acetone series and, then, embedded in Spurr soft mixture. $3 \mu \mathrm{m}$ thick sections were stained with toluidine blue and observed with LM. Ultra-thin sections were stained with $1 \%$ uranyl acetate for $15 \mathrm{~min}$, 
followed by lead citrate for $5 \mathrm{~min}$. In Pteridium arachnoideum, some ultra-thin sections were stained with $1 \%$ uranyl acetate for $15 \mathrm{~min}$, followed by lead citrate for $2.3 \mathrm{~min}$.

The observations with LM were performed with an Olympus BH2 LM and those of the spore surface with a JEOL JSMT-100 SEM. The observations were made with a Zeiss M-10 TEM.

The samples were deposited at the Laboratorio de Palinología from Facultad de Ciencias Naturales y Museo de La Plata (La Plata, Argentina). The letters MP, in the list of specimens investigated indicate the reference number of each palynological sample filed.

To morphological and ultrastructural descriptions we used the work of Kremp (1965), Nayar and Devi (1966), Tryon and Lugardon (1991), Punt et al. (1994, 2007) and Lellinger (2002).

STUDIED MATERIAL

\section{Microlepia speluncae}

Brazil: Rio de Janeiro; Estrada de la Covonca, 30/09/1959, De la Sota 2298 (LP); Teresópolis, Parque Nacional da Serra dos Órgãos, 14/01/2008, Labiak et al. 4522 (UPCB). São Paulo, Tiete, 02/12/1906, Gerdes 94 (HB); Mun. Teodoro Sampaio, Pontal do Paranapanema, Parque Estadual Morro Do Diabo, 30/01/1995, Silva 1680 (MO); Santa Catarina, Hammonia, 07/1910, Luederwaldt s/n (SP). Paraguay: Guairá, Cerro de Villa Rica, 04/1924, Rojas 4878 (MO).

\section{Pteridium arachnoideum}

Argentina: Corrientes, Ituzaingó. Isla Apipé Grande, Panco cué, 05-Oct-1978, Schinini \& Vanni 15792 (MO). Misiones, Dpto. 2 de Mayo, Colonia 2 de Mayo, 22-May-1951, Cabrera et al. 335 (LP); Dpto. San Pedro, ruta 14 entre San Pedro y Fracran, km 327, 16-Dic-1970, De la Sota et al. 6167 (LP). Brazil: Paraná, Mun. Tijucas do Sul, Capina 46 km S de Curitiba, 14-Feb-1978, Krapovickas \& Cristóbal 33652 (LP); Mun. São Mateus do Sul,
BR-476, km 152, 26-Jan-1985, Krapovickas \& Cristóbal 39667 (LP). Rio Grande do Sul, Rio Pardo, 1906, Rosenstock $267^{a}$ (SI). São Paulo, estrada entre São Paulo e São Roque, 15-July1972, Siegel 25 (HB). Paraguay: Caazapá, Tavai, $2 \mathrm{~km}$ del destacamento, 21-Dic-1988, Soria 3020 (MO); Tavai, Cerro Tupasy, 29-Oct-1988, Degen 906 (MO).

\section{RESULTS}

The spores of Microlepia speluncae (Fig. 1) and Pteridium arachnoideum (Fig. 2) from Paranaense Province are trilete, triangular to globose in polar view, with straight to concave or convex sides and rounded corners (Figs. 1a-b, 2a-b). In equatorial view the spores are plane-hemispheric, sometimes convex-subconic in P. arachnoideum (Figs. 1c, 2c).

The laesurae are straight extending $3 / 4$ of the way to the equator, and generally are covered by ornamentation (Figs. 1d-e, 2d). With LM the exospore is light brown-yellowish and the perispore is brown. The morphological data of the spores of $M$. speluncae and $P$. arachnoideum are summarized in Table I.

\section{Spore morphology}

The spore surface bears a three-dimensional network of threads in both species. In Microlepia speluncae the basal threads are cylindrical, circular in section, with smooth surface, uniformly distributed, and they are tangentially oriented to the spore surface (Fig. 1d-f). Some of these threads of about are 0.5-2.6 $\mu \mathrm{m}$ long and extend perpendicularly from the surface and may be fused at their tips to form spinules (Fig. 1g). Sometimes, a granular layer covers the threads background and only the tangential threads can be observed (Fig 1h-i). In Pteridium arachnoideum the threads are shorter than those in Microlepia speluncae, flattened, with sharp tips like spinules, and with a microverrucate surface (Fig. 2d-g). 

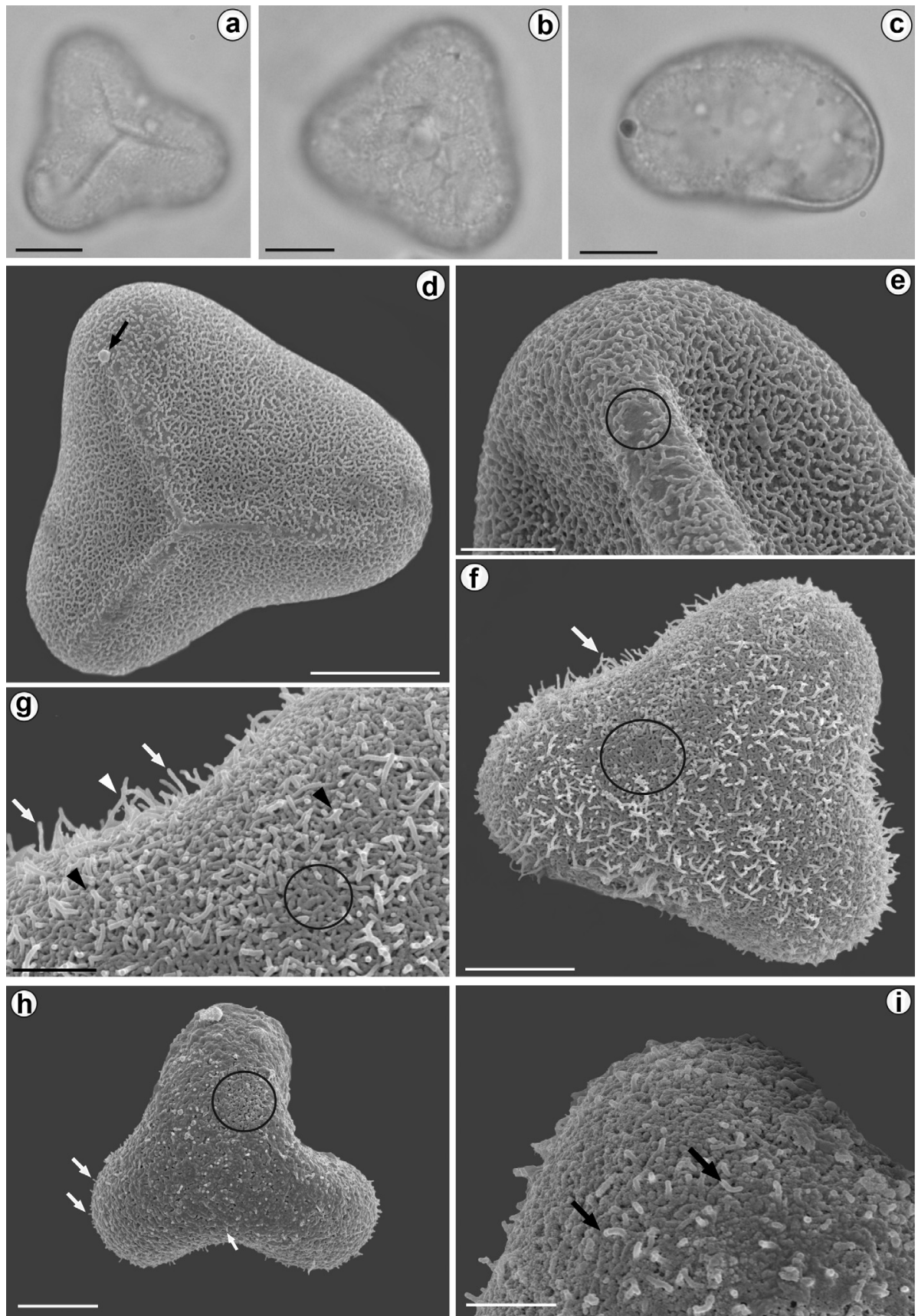

Figure 1 - Spores of Microlepia speluncae with LM (a-c) and SEM (d-i). a. Spore in proximal view. Scale bar $=10 \mu \mathrm{m}$. b. Spore in distal view. Scale bar $=10 \mu \mathrm{m}$. c. Spore in equatorial view. Scale bar $=10 \mu \mathrm{m}$. d. Spore in proximal view. The spore surface bears a three-dimensional network of branching threads. Spheroids are observed (arrow) Scale bar $=10 \mu$ m. e. Detail of the proximal view. The laesurae are partially covered of threads. An irregular surface below the threads network is observed (circle). Scale bar $=6 \mu \mathrm{m}$. f. Spore in distal view. The ornamentation is formed of a three-dimensional network of fused and ramified thread (circle). Some threads, oriented perpendicular to the surface are evident, which are higher on the spore sides (arrows). Scale bar $=10 \mu \mathrm{m}$. g. Detail of the distal surface, formed of threads tangentially (circle) and perpendicular (arrow) oriented. Some of the last ones are fused at the top to form spinules (arrowhead). Scale bar $=6 \mu \mathrm{m}$. h. Spore in distal view. A granular layer covers the threads background, and only the perpendicular threads can be observed (arrow). Threads tangentially oriented to the spore surface are only visible where the granular layer is not present (circle). i. Detail of the distal surface. The tips of the threads tangentially oriented are evident (arrow). Scale bar $=5 \mu \mathrm{m}$. 
There are variations in the fusion degree of the threads and in the complexity of the network, so, occasionally, some masses of threads can be observed. The variation in the perispore thickness is the result of the heterogeneous threads distribution
(Fig. 2d-f). Spheroids are also seen distributed on the spore surface (Figs. 1d, 2g).

An irregular surface below the three-dimensional network of threads is observed in both species (Fig. 1e).
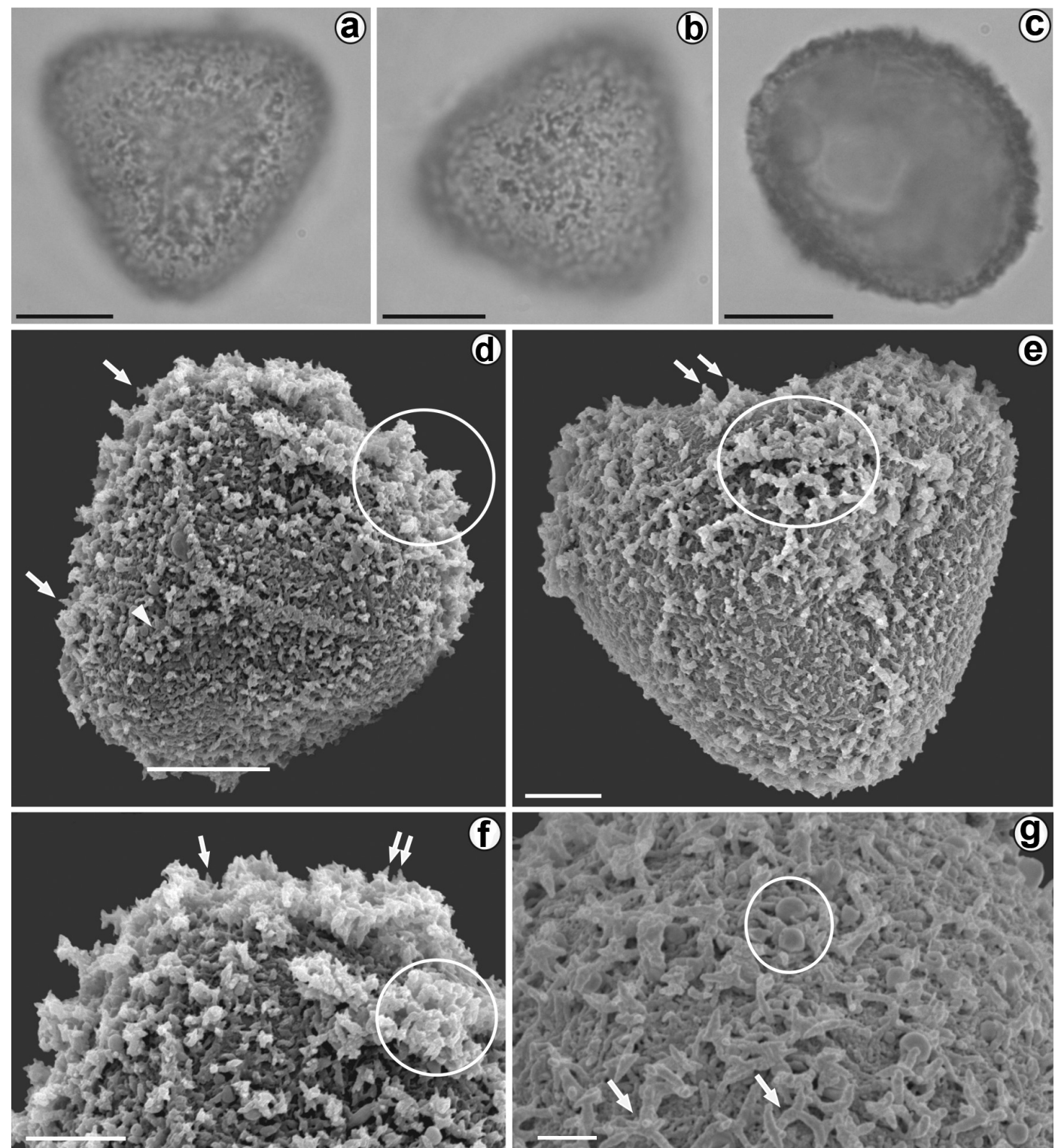

Figure 2 - Spores of Pteridium arachnoideum with LM (a-c) and SEM (d-g). a. Spore in proximal view. Scale bar $=10 \mu \mathrm{m}$. b. Spore in distal view. Scale bar $=10 \mu \mathrm{m}$. c. Spore in equatorial view. Scale bar $=10 \mu \mathrm{m}$. d. Spore in proximal view. Short threads with spinulate tips (arrow) are fused to form agglomerations (circle). The ornamentation covers the laesura (arrowhead). Scale bar $=10 \mu \mathrm{m}$. e. Spore in distal view. The threads (arrows) are distributed at random on the spore surface and areas with big agglomerations of them are observed (circle). Scale bar $=5 \mu$ m. f. Surface detail in proximal view. Fused threads (arrow) form agglomerations (circle). Scale bar $=5 \mu \mathrm{m}$. g. Detail of the surface in distal view. The threads are ramified and fused to form a massive network (arrow). Dispersed spheroids are observed (circle) Scale bar $=2 \mu \mathrm{m}$. 
TABLE I

Characteristics of Micolepia speluncae and Pteridium arachnoideum spores.

\begin{tabular}{|c|c|c|c|}
\hline & & Microlepia speluncae & Pteridium arachnoideum \\
\hline Shape & & Tetrahedral & Tetrahedral \\
\hline \multirow{2}{*}{\multicolumn{2}{|c|}{ Laesura }} & Trilete & Trilete \\
\hline & & $9-14 \mu \mathrm{m}(3 / 4$ of ratio $)$ & $7-14 \mu \mathrm{m} . \quad(3 / 4$ of ratio). \\
\hline \multicolumn{2}{|l|}{ PS } & $\begin{array}{l}\text { Triangular. Rounded corners, straight to } \\
\text { concave sides. }\end{array}$ & $\begin{array}{l}\text { Triangular to globose. Rounded corners, } \\
\text { straight to convex sides. }\end{array}$ \\
\hline \multirow{2}{*}{\multicolumn{2}{|c|}{ ES }} & Proximal face, plane & Proximal face, plane to convex \\
\hline & & Distal face, hemispheric & Distal face, hemispheric to subconic \\
\hline \multicolumn{2}{|l|}{ PD } & $22(36) 31 \mu \mathrm{m}$ & $22(28) 39 \mu \mathrm{m}$ \\
\hline \multicolumn{2}{|l|}{$\mathbf{D E}>$} & $29(35) 45 \mu \mathrm{m}$ & $27(36) 46 \mu \mathrm{m}$ \\
\hline \multicolumn{2}{|l|}{$\mathbf{D E}<$} & $27(34) 39 \mu \mathrm{m}$ & $22(34) 44 \mu \mathrm{m}$ \\
\hline \multirow{2}{*}{ Exospore } & Color (LM) & Light brown-yellowish & Light brown-yellowish \\
\hline & Wall thickness & $0.7-1.5 \mu \mathrm{m}$ & $0.3-0.6 \mu \mathrm{m}$ \\
\hline \multirow{4}{*}{ Perispore } & Color (LM) & Brown & Brown \\
\hline & Wall thickness & $0.1-3 \mu \mathrm{m}$ & $0.2-2.7 \mu \mathrm{m}$ \\
\hline & Ultrastructure & $\begin{array}{l}\text { Substructural elements: Threads. } \\
\text { Open three-dimensional network }\end{array}$ & $\begin{array}{l}\text { Substructural elements: Threads. } \\
\text { Massive three-dimensional network }\end{array}$ \\
\hline & Ornamentation & $\begin{array}{l}\text { Spinulate } \\
\text { Backgraund reticulate }\end{array}$ & $\begin{array}{l}\text { Spinulate } \\
\text { Backgraund reticulate }\end{array}$ \\
\hline
\end{tabular}

PS: Shape in polar view; ES: Shape in equatorial view; PD: polar diameter; DE: Equatorial diameter; >: Mayor; <: Minor.

\section{Sporoderm ultrastructure}

The exospore of Microlepia speluncae and Pteridium arachnoideum is two-layered in TEM sections. The inner layer (iE) is thin, with low electrondensity and a homogeneous structure (Figs. 3a, $4 a-b)$. The outer layer (oE) is thicker than $\mathrm{iE}$ and it is formed of two strata: the inner stratum $\left(\mathrm{oE}_{2}\right)$ with short channels, fissures and cavities filled with an electron-dense material; and the outer stratum $\left(\mathrm{oE}_{1}\right)$, thicker than $\mathrm{oE}_{2}$, with margin and a homogeneous structure (Figs. 3a-b, d, 4a-b).

The $\mathrm{oE}_{2}$ channels are connected with those present in $\mathrm{oE}_{1}$ (Figs. 3d, 4b). Occasionally, the $\mathrm{oE}_{1}$ channels are ramified and continuous with those of the perispore (Fig. 4a-b).

The perispore has a higher electron-density than that of the exospore with TEM, and three layers can be seen in both species. The inner layer (iP) is $20-80 \mathrm{~nm}$ thick, with irregular margin, homogeneous structure, and it is adhered to the exospore (Figs. 3a, d, 4c, d). The middle layer (mP) is $0.2-2.6 \mu \mathrm{m}$ thick and it is constituted of a three- dimensional network of threads. In $M$. speluncae the threads are $0.2-0.3 \mu \mathrm{m}$ thick in section and are spaced apart, forming an open network. Threads can be fused at the tip (Fig. 3e-f) or through cross elements (Fig. 3g), and the core and the periphery of them are more electron-dense than those in the middle area (Fig. 3d, g).

In $P$. arachnoideum the treads of $\mathrm{mP}$ have a uniform electron-density and are close arranged forming a massive network (Fig. 4c-d). Cavities filled with an electron-dense material are observed among the threads of the netwok (Fig. 4d).

The outer layer $(\mathrm{oP})$ covers the $\mathrm{mP}$ threads and it is discontinuous, with low electron-density and a homogeneous structure (Figs. 3e, a, 4c, d).

Two kinds of spheroids of $0.2-1 \mu \mathrm{m}$ diameter are observed within the perispore. In M. speluncae, the spheroids have the same structure and electrondensity than that of the perispore (Fig. 3a). However, the $P$. arachnoideum spheroids have a central core like the exospore, and they are covered by a substance similiar to that of the perispore (Fig. 4f). 


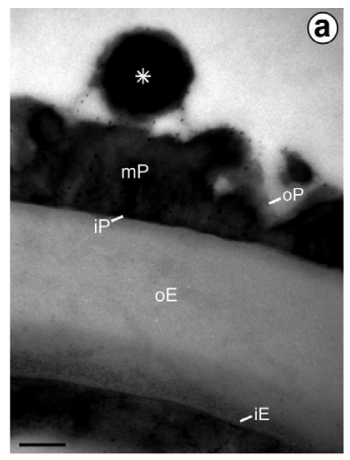

(a)
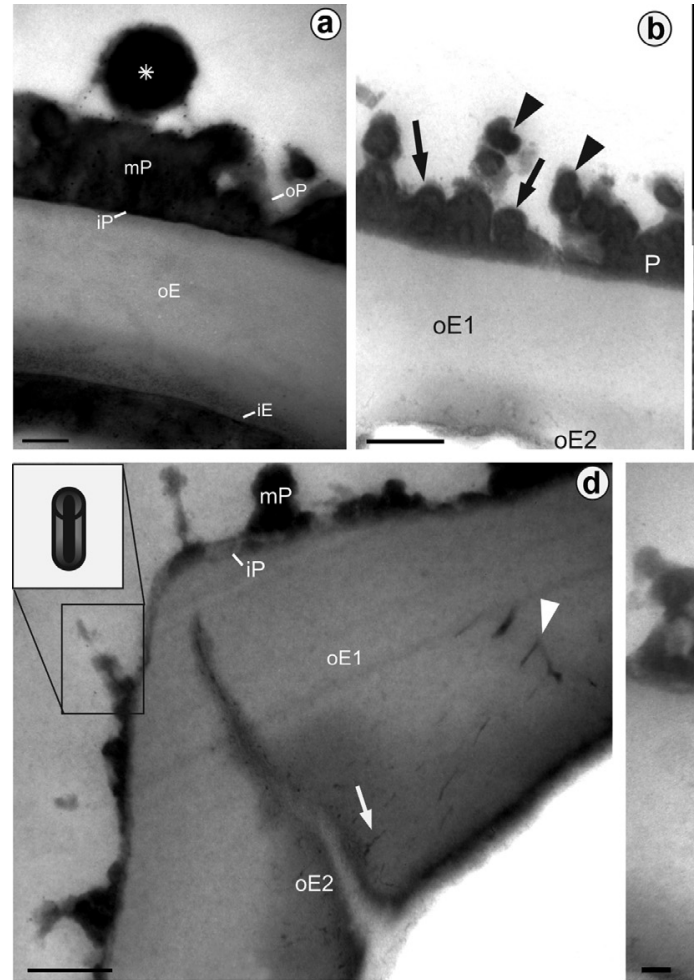

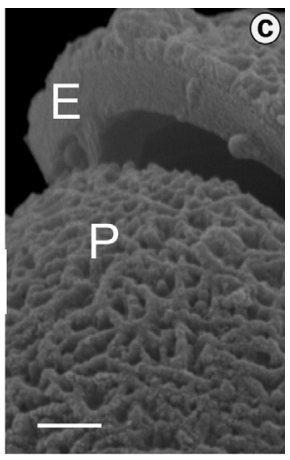

(e)

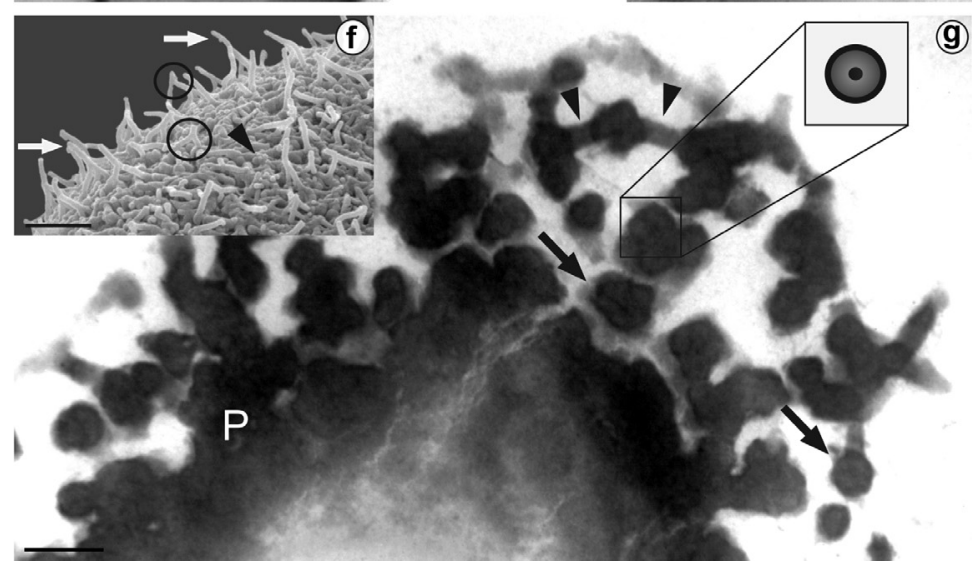

Figure 3 - Spores of Microlepia speluncae with TEM (a-b, d-e, g) and SEM (c, f). a. In this picture, the inner exospore (iE) is thin, with a homogeneous structure and low electron-density. Spheroids with the same ultrastructure and electron-density than perispore are observed (asterisk). Outer exospore (oE), inner perispore (iP), medium perispore (mP), outer perispore (oP). Scale bar $=0.4 \mu \mathrm{m}$. b. Section through the sporoderm, where: $\left(\mathrm{oE}_{2}\right.$ shows short channels, fissures and cavities filled with an electron-dense material; and $\left(\mathrm{oE}_{1)}\right.$ is thicker than the inner one, with irregular outer margin and homogeneous structure. The perispore $(\mathrm{P})$ is formed of threads tangential (arrows) and perpendicular oriented (arrowheads). Scale bar $=0.4 \mu \mathrm{m}$. c. Sporoderm fracture with SEM. The Perispore $(\mathrm{P})$ threads cover the exospore $(\mathrm{E})$. Scale bar $=1 \mu \mathrm{m}$. d. Section through the lesurae. In the inner stratum fissures and cavities filled with an electron-dense material (arrow) are present $\left(\mathrm{oE}_{2}\right)$. The outer stratum $\left(\mathrm{oE}_{1}\right)$ is thicker than $\mathrm{oE}_{2}$, with an irregular margin, homogeneous structure, and has channels (arrowhead). The inner perispore (iP) is thin; the middle perispore (mP) has threads with a central core and peripheral area more electron-denser than middle area (scheme). Scale bar $=0.4 \mu \mathrm{m}$. e. The medium layer $(\mathrm{mP})$ forms a three-dimensional network of threads. The outer layer $(\mathrm{oP})$, is discontinuous; low electron-dense and shows an homogeneous structure. Threads can be fused at the tip (circle). Exospore (E). Scale bar $=0.1 \mu \mathrm{m}$. f. The threads of the ornamentation are fused and form a tangential network (arrowhead), with some perpendicular elements (arrows). The perpendicular threads could fuse at the top forming spinules (circles) Scale bar $=2 \mu \mathrm{m}$. g. Section through the sporoderm at a spore corner. The threads (arrow) have a central core and a periphery more electron-denser than the medium area (scheme). Some threads are fused (arrowhead). Scale bar $=0.4 \mu \mathrm{m}$. P = Perispore. 

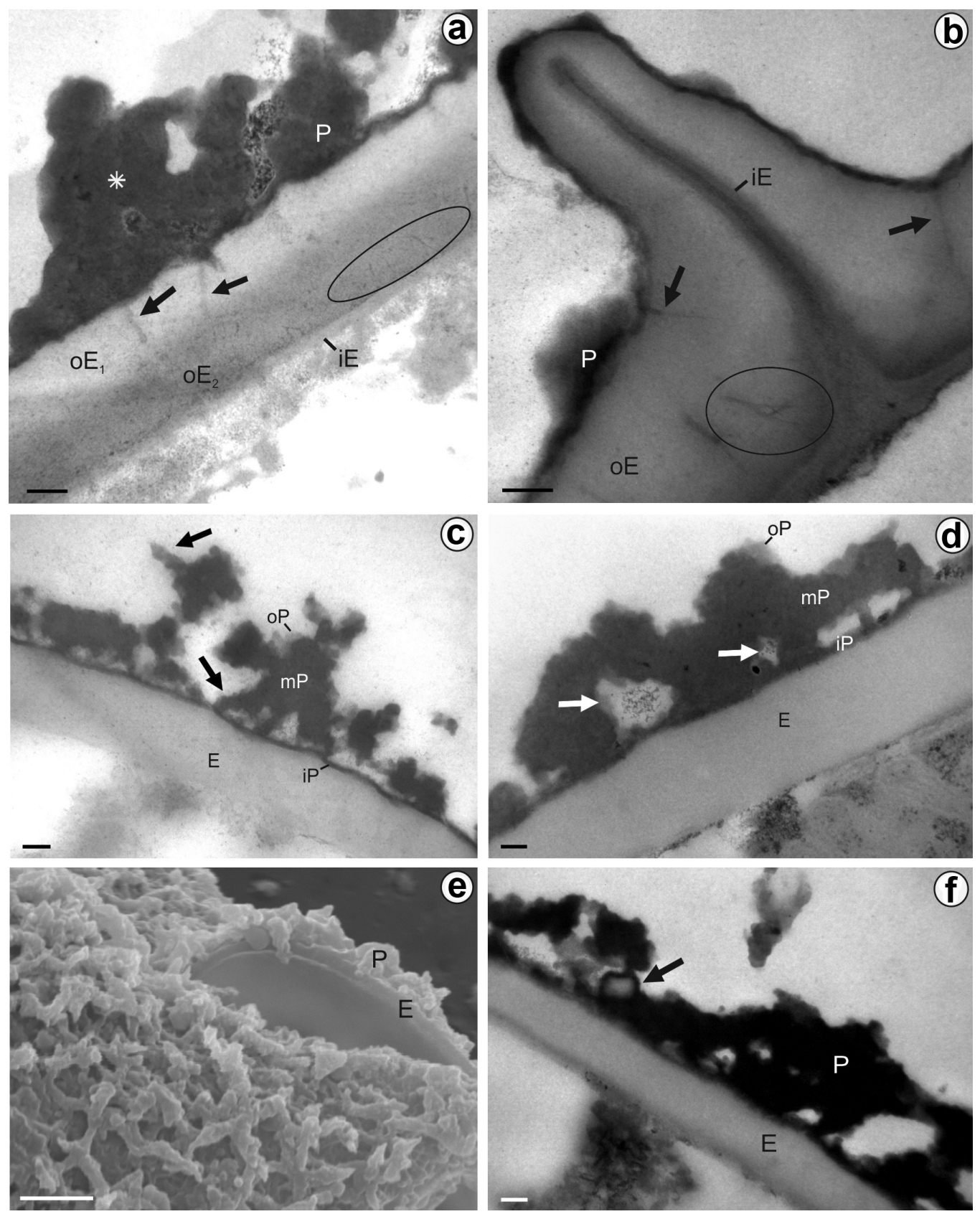

Figure 4 - Spores of Pteridium arachnoideum with SEM (e) and TEM (a-d, f). a. The threads of perispore are fused in massive networks (asterisk). The inner exospore $(\mathrm{iE})$ is thin, with homogeneous structure. The inner stratum of the outer exospore $\left(\mathrm{oE}_{2}\right)$ has fissures and short, ramified channels (circle). The channels (arrows) of the outer stratum $\left(\mathrm{oE}_{1}\right)$ are continuous with the perispore (P). $2.3 \mathrm{~min}$ in $\mathrm{Pb}$-c. Scale bar $=0.2 \mu \mathrm{m}$. b. Section through the lesurae. The inner exospore (iE) can be seen at the lesura base. The channels of the outer exospore are ramified (circle) and show continuity with that of the perispore (arrow). Perispore (P). 5 min in $\mathrm{Pb}$-c. Scale bar $=0.1 \mu \mathrm{m}$. oE $=$ outer exospore. c. The inner perispore (iP) is homogeneous and it is attached to the exospore. The middle perispore $(\mathrm{mP})$ is formed of threads. The threads (arrow) have verrucose margin, narrow and fused tips. The outer perispore (oP) is discontinuous, with low electron-density. Exospore (E). $2.3 \mathrm{~min}$ in $\mathrm{Pb}$-c. Scale bar $=0.5 \mu \mathrm{m}$. d. Cavities filled with electrondense material are observed among threads in the network (arrow). Inner perispore (iP); middle perispore (mP); outer perispore (oP); exospore (E). $2.3 \mathrm{~min}$ in Pb-c. Scale bar $=0.1 \mu \mathrm{m}$. e. Wall fracture with SEM. Threads of perispore $(\mathrm{P})$ cover the exospore $(\mathrm{E})$. Scale bar $=0.2 \mu \mathrm{m}$. f. Spheroids are observed in the perispore (arrow). They have a central core like exospore, which is covered by a substance similar to that of the perispore. Perispore (P). Exospore (E). $5 \mathrm{~min}$ in Pb-c. Scale bar $=0.2 \mu \mathrm{m}$. 


\section{DISCUSSION}

Microlepia speluncae and Pteridium arachnoideum spores are covered by a three-dimensional network of branched and fused threads, tangentially arranged to the surface, and some free-end threads, frequently spinule-like, are seen. According to our interpretation the threads are observed under the LM as small spheroidal processes. For the reasons given above, we understood that the spores of both species could be interpreted by previous authors as granular (Selling 1946, Nayar and Devi 1968a, Welman 1970, Lugardon 1971, Soepadmo and Khoo 1977, Devi 1977, Lorscheitter et al. 2002, Esteves and Coelho 2007), fossulate or foveolate (Erdtman and Sorsa 1971), scabrate (Harris 1955, Belling and Heusser 1975, Contreras-Duarte et al. 2006), verrucate (Tardieu-Blot 1966); psilate (Welman 1970, Kremp and Kawasaki1972). Only Large and Braggins (1991) described granules formed of threads, similar to that observed in this work.

In this sense, the use of scanning electronic microscopy was essential to achieve a better understanding of spore three-dimensional structures.

Although the studied species have the same morphology, ornamentation and fusion degree from the threads and the networks distribution on the surface of the spores varies in both cases. In Microlepia speluncae the threads are cylindrical, circular in section, with smooth surface. These threads are usually fused at tips, they are spaced by wide distances defining an open three-dimensional networks. Additionally, the networks complexity is uniform across the surface of the spores. In contrast, in Pteridium arachnoideum the network complexity is highly variable and is related to fusion degree reached by the threads. The threads are separated by narrow spaces and can merge completely to form massive networks or masses. In this species the threads are short, flatt, with sharp tips like spinules and have a microverrucate surface.
Regarding the sporoderm stratification, our observations agree in part with those obtained by Tryon and Tryon (1982) for M. speluncae but those authors made different interpretation about perispore layers structure. These authors describe with SEM an inner layer formed of strands, a middle granular layer and an outer layer bearing spinules on the surface. Based in TEM observations, we believe that the perispore inner layer is homogeneous with an irregular margin, the middle layer is formed of threads, and the outer layer is discontinuous and not very apparent. Respect to the middle granular layer described by Tryon and Tryon is for us the granular layer that covers the background of threads. This layer was not identified under TEM analysis and therefore, was not defined by us as forming part of the sporoderm, but could be associated with tapetal remains or material deposited during processing.

Regarding the $P$. arachnoideum sporoderm ultrastructure, Tryon and Tryon (1982) described a granulate perispore with a fused mass or rodlets, in agreement with Lugardon $(1971,1974)$ and Tryon and Lugardon (1991) observations. In our interpretation, the granular processes covering the spores of this species would be the result of the threads fusion.

Respect to the existence of several opinions about the structure and stratification of the spore wall, may be due to the fact that, for a same specimen, there are spores in different stages of development.

The perispore formed by threads (described as "rodlets") was also observed in other fern groups such as Matoniaceae, Vittariaceae, Lindsaeaceae and Pteridaceae (Tryon and Lugardon 1991). Furthermore, in genus Syngamma, Ceratopteris (Tryon and Lugardon1991), Cheilanthes (Morbelli and Michelena 1989) and Cyathea (Marquez et al. 2010), the threads form three-dimensional networks.

In all of the above mentioned groups, the threads have a low electron-density core. This 
characteristic differ from the substructure of those described in this work for M. speluncae. A crosssection view of threads for this species allow to observe the margins and very electron-dense centers, reminiscent of the ones present in some Dicksonia species (Tryon and Lugardon 1991). The substructure of the threads observed in $M$. speluncae shows similarities with that mentioned by several authors for lycophytes (Rowley 1995, Wittborn et al. 1998), ferns (Marquez and Morbelli 2015) and angiosperms (Rowley 1981, 1987, Blackmore 1990). In all of these cases, the authors described them as formed by helical subunits displayed around an axis or central channel. Furthermore, Rowley et al. (2003) suggested that the central channel would take part in the transfer of nutrients from the tapetum to the spore cytoplasm during the stages of development.

On the other hand, in $P$. arachnoideum the threads do not show any substructural difference of electron-density like $M$. speluncae and are similar to the coiled rods or coiled threads described both in lycophytes (Morbelli 1995) as well as in ferns (Marquez et al. 2009). In this sense, the microverrucae observed on P. arachnoideum threads could be interpreted as spiral loops. Even though in this work no presence of a central channel in threads of this species was found, new studies based on fresh material and other fixations are needed for confirmation. Additionally, in our experience, the perispore threads in $P$. arachnoideum were better observed in ultra-thin sections that were submerged in lead citrate for $2.3 \mathrm{~min}$ as compared to ultra-thin sections submerged for 5 min. Similarly, Rowley (1987) concluded that the intensity of staining and the complexity of images of the sporoderm processes were inversely proportional to duration of the sections immersion in lead citrate.

Even though the presence of threads in phylogenetically distant groups shows the limited value of this feature to differentiate families, perispore ornamentation allows to differentiate the studied species from other genus of the same family present in the area, which have verrucate spores in Dennstaedtia globulifera, D. cicutaria, D. obtusifolia and D. cornuta (Yañez et al. 2011), baculate spores in Blotiella lindeniana, regulate spores in Paesia glandulosa, psilate in Histiopteris incisa or cristate-echinulate spores in Hypolepis stolonifera $H$. repens and $H$. rugosula (Yañez et al. 2013).

Furthermore, based on morphology, substructure and threads organization we are able to differentiate Pteridium and Microlepia species from Paranaense Province. In this sense, perispore ultrastructure and ornamentation are useful to characterize genus or subgeneric groups within the same family, a conclusion made also by Tryon (1986), Korall and Taylor (2006), Moran et al. (2007) and Triana-Moreno (2012).

Regarding the exospore, the features observed for the studied species adjust to "the blechnoide type" described by Lugardon $(1971,1974)$. The channels and cavities network of the innermost stratum observed in this work match the "strata fissurée" described by the French author. The other species of Dennstaedtiaceae from study area also have this type of exospore. However, in Blotiella, Paesia, Histiopteris and Hypolepis the exospore margin is ornamented by clavae, tubercle, spines or verrucae.

The disperse spheroidal bodies observed by SEM on spores of both species are similar to those described by Giudice et al. (2006) and Yañez et al. (2011) in Dennstaedtia, for the same family. We observed the spheroids with TEM and they have a central structure similar to that of the exospore, wrapped in a perispore-like layer in $P$. arachnoideum, and they were similar to those defined as globules (Lugardon 1974, Tryon and Lugardon 1991). On the contrary, spheroids found in $M$. speluncae do not show electron-density variation and appear to have a substance similar to that of the perispore, whereby we concluded 
that they are spherules (Lugardon 1974, Tryon and Lugardon 1991).

\section{CONCLUSIONS}

In Microlepia aspeluncae and Pteridium arachnoideum, the use of electronic microscopy is necessary in order to achieve a better interpretation of spores morphology due to the threads features conforming their ornamentation.

The ultrastructure observed in the spores of Microlepia speluncae perispore could be due to the helical subunits displayed around an axis or central channel as proposed by Rowley (1981).

The perispore morphology and ultrastructure would allow to differentiate not only Microlepia from Pteridium but also the other Dennstaedtiaceae genera of the Paranaense Phytogeographic Province.

\section{ACKNOWLEDGMENTS}

The authors thank the institutions that provided the studied materials, Mrs. Isabel Farías for help in technical aspects of TEM sample processing and sectioning and Ing. Lisandro Anton for his willingness to provide help selflessly during observations with MET. This work was supported by grants from Agency of Promotion of Science and Technology (ANPCyT) PICT 0661 and Universidad Nacional de La Plata for Projetc N584.

\section{RESUMO}

A morfologia dos esporos e a ultraestrutura da parede do Microlepia speluncae e Pteridium arachnoideum da Província Paranaense foram analisadas com LM, SEM e TEM e uma análise comparativa foi realizada. Em ambas as espécies, os esporos são cobertos por uma rede tridimensional de cordões ramificados e fundidos, dispostos tangencialmente à superfície, e alguns fios com extremidades livres também são vistos. As espécies foram diferenciadas pela morfologia e a frequência de fusão de fios e redes de distribuição sobre a superfície dos esporos. Em ambas as espécies a exospore é de duas camadas na seção, ambas as camadas são atravessadas por canais únicos ou ramificados. O perisporo é de três camadas na seção: a camada interna é aderida à exospore, a camada do meio é formada por uma rede tridimensional de cordões e a camada exterior é descontínua. A ultraestrutura do perisporo de Microlepia speluncae foi interpretada como formada por subunidades helicoidais exibidas em torno de um canal central. A morfologia dos esporos e ultraestrutura do perisporo permitem diferenciar Microlepia de Pteridium, mas também para os outros gêneros Dennstaedtiaceae que crescem na Província Paranaense. Os resultados obtidos permitem estabelecer relações que nos permitem reconhecer diferentes grupos e nos deu uma nova referência para obter um melhor conhecimento da família.

Palavras-chave: Esporos, ultraestrutura, Dennstaedtiaceae, Província Paranaense, Microlepia speluncae, Pteridium arachnoideum.

\section{REFERENCES}

ANTON AM AND ZuloAgA FO. 2014. Flora Argentina. http:// www.floraargentina.edu.ar/; accessed 29 May 2014.

ASSIS FC AND SALINO A. 2011. Dennstaedtiaceae (Polypodiaceae) no estado de Minas Gerais, Brasil. Rodriguésia 62(1): 11-33.

BELling AJ AND HEUSSER CJ. 1975. Spore Morphology of the Polypodiaceae of Northeastern North America. II. B Torrey Bot Club 102(3): 115-127.

BLACKMORE S. 1990. Sporoderm homologies and morphogenesis in land plants, with a discussion of Echinops sphaerocephala (Compositae). In: Hesse M et al. (Eds), Morphology, Development, and Systematic Relevance of Pollen and Spores, Springer Vienna, p. 1-12.

CABrera AL AND WiLlinK A. 1973. Biogeografía de América latina, Monografía 13, Serie de Biología. Washington: Secretaría General de la Organización de los Estados Americanos, $123 \mathrm{p}$.

CONTRERAs-DuARTE AR, GIOVANNI BOGOTÁ-ÁNGEL RG AND JiMÉNEZ-BULlA LC. 2006. Atlas de las esporas de Pteridófitos de Chipaque (Cundinamarca, Colombia). Caldasia 28(2): 327-357.

CONWAY E. 1949. The autecology of bracken (Pteridium aquilinum (L.) Kuhn): the germination of spore, and the development of the prothallus and the young sporophyte. Proc Roy Soc Edinburgh 63: 325-346.

CONWAY E. 1957. Spore production in bracken. J Ecology 45: 273-284.

COOPER-DRIVER G. 1976. Chenotaxonomy and phytochemical ecology of bracken. Bot J Linn Soc 73: 35-46. 
COPELAND EB. 1947. Genera Filicum. The genera of ferns. Chronica Botanica. Annales Cryptogamici et Phytopathologici 5. Waltham: Chronica Botanica, $247 \mathrm{p}$.

DEN-OUDEN D. 2000. The role of bracken (Pteridium aquilinum) in forest dynamics. $\mathrm{PhD}$ Thesis, Wageningen University, Wageningen, Neetherlands.

DER JP, THOMSON JA, STRATFORD JK AND WOLF PG. 2009. Global chloroplast phylogeny and biogeography of bracken (Pteridium; Dennstaedtiaceae). Am J Bot 96(5): 1041-1049.

DEVI S. 1977. Spores of Indian Ferns. New Delhi: Today and Tomorrow's Printers \& Publishers, 228 p.

ERdTMAN G. 1957. Pollen and Spore Morphology, Plant Taxonomy: Gymnospermae, Pteridophyta, Bryophyta. Stockholm: Almqvist \& Wiksell, 147 p.

ERDTMAN G. 1960. The acetolysis method. A revised description. Sven Bot Tidskr 54: 561-564.

ERdTMAn G AND SorSA P. 1971. Pollen and spore morphology/Plant taxonomy. Pteridophyta (texts and additional illustrations). An introduction to Palynology, IV. Stockholm: Almqvist \& Wiksell, 300 p.

ESTEVES LM AND COELHO CB. 2007. Morphology of spores of pteridophyte from the Parque Estadual das Fontes do Ipiranga (São Paulo, Brazil): 5. Dennstaedtiaceae. Hoehnea 34(2): 245-252.

Giudice GE, Morbelli MA, MaCluf CC, HeRnANDEZ M AND RUIZ A. 2006. Morphology and ultrastructure of the spores of Dennstaedtiaceae from North West Argentina. Rev Palaeobot Palyno 141: 245-257.

GRAF-MEIER K. 1985. Esporas triletes de helechos bolivianos. Boletín del Servicio Geológico de Bolivia, Serie A 3(1): 33-51.

HARRIS WF. 1955. A manual of the spores of New Zealand Peridophyta. Christchurch: N. Z. Wellington, 187 p.

HUANG TC. 1981. Spore flora of Taiwan. Taiwan: National Taiwan University, p.105-111.

KNOX EM. 1938. The spores of Pteridophyta, with observations on microspores in coals of Carboniferous age. Trans Bot Soc Edin 32(3): 438-466.

KORALL P AND TAYLOR WA. 2006. Megaspore morphology in the Selaginellaceae in a phylogenetic context: A study of the megaspore surface and wall structure using scanning electron microscopy. Grana 45(1): 22-60.

KRAMER KU AND GREEN PS. 1990. Pteridophytes and Gymnospermes. In: Kubitzki K (Ed), The Families and Genera of Vascular Plants, vol. 1. Berlin: Springer-Verlag, p. 81-94.

KREMP GOW. 1965. Morphologic Encyclopedia of Palynology: An Internat. Coll. of Definitions and Ill. of Spores and Pollen. Tucson: University of Arizona Press, 263 p.

KREMP GOW AND KAWASAKI T. 1972. The Spores of the Pteridophytes: Illustrations of the Spores of the Ferns and Fern Allies; a Guide to the Type Species of the Extant
Genera of the Pteridophytes, and to Selected Extinct Spore Genera. Volume 42, Hirokawa Publishing Company ed., Dept. of Geosciences, University of Arizona Press, Arizona, 398 p.

LARGE MF AND BRAGGINS JE. 1991. Spore atlas of New Zealand ferns and ferns allied. New Zeal J Bot 29: 1-68.

LELLINGER DB. 2002. A modern multilingual glossary for taxonomic pteridology. Pteridologia 3: 1-263.

LORSCHEITTER ML, ASHRAF A, WINDISCH P AND Mosbrugger V. 2002. Pteridophytes spores of Rio Grande do Sul, Brazil: Part IV. Paleontogr. Abt B 263: 1-159.

LUGARDON B. 1971. Contribution á la connaisance de la morphogénese et de la structure des paroissporaleschez les Filicinéesisosporées. PhD Thesis, Univ. P. Sabatier Toulouse, France.

LUGARDON B. 1974. La structure fine de l'exospore et de la périspore des Filicinéesisosporées, II. Filicales commentaries. Pollen Spores 16: 161-226.

MARQuez GJ AND Morbelli MA. 2015. Substructural components in the sporoderm of the Family Cyatheaceae. Palynology 39(2): 37-41.

Marquez GJ, Morbelli MA AND Giudice GE. 2009. Comparative analysis of spores of Alsophila (Cyatheaceae) species from southern South America. Rev Palaeobot Palyno 156(1): 165-176.

MARQUEZ GJ, MORBELli MA AND GIUDICE GE. 2010. Spore morphology and ultrastructure of Cyathea (Cyatheaceae, Pteridophyta) species from southern South America. Grana 49(4): 269-280.

MiCKEL JT AND SMITH AR. 2004. Pteridophytes of Mexico. Mem N Y Bot Gard 88: 1-1055.

MORAN RC, HANKS JG AND ROUHAN G. 2007. Spore morphology in relation to phylogeny in the fern genus Elaphoglossum (Dryopteridaceae). Int J Plant Sci 168(6): 905-929.

Morbelli MA. 1980. Morfología de las esporas de las Pteridophyta presentes en la Región Fuego-Patagónica. República Argentina. Opera Lilloana 28: 1-138.

MORBELli MA. 1995. Megaspore wall in Lycophytaultrastructure and function. Rev Palaeobot Palyno 85(1): $1-12$.

Morbelli MA AND MichelenA IG. 1989. Palynological analysis of Cheilanthes species (Adiantaceae-Pteridophyta) of northwestern Argentina. Grana 28(4): 295-304.

MorRone JJ. 2001a. Biogeografía de América Latina y el Caribe, Manuales \& Tesis SEA, Vol. 2. Zaragoza: Sociedad Entomológica Aragonesa, 144 p.

MORRONE JJ. 2001b. The Paraná subregion and its provinces. Physis Secc C 58(134-135): 1-7.

MorRone JJ. 2014. Biogeographical regionalisation of the Neotropical region. Zootaxa 3782(1): 1-110.

NAYAR BK AND DEVI S. 1966. Spore morphology of the Pteridaceae I. The Pteridoid ferns. Grana 6(3): 476-502. 
NAYAR BK AND DEVI S. 1968a. Spore morphology of the Pteridaceae III. The Dicksonioid, Dennstaedtioid and Lindsaeoid ferns. Grana 8(1): 185-203.

NAYAR BK AND DEVI S. 1968b. Spore Morphology of the Pteridaceae IV. Taxonomic and Phyletic Considerations. Grana 8(2-3): 517-535.

Ponce MM, PRAdo J AND Sota DE LA ER. 2008. Dennstaedtiaceae. In: Zuloaga FO et al. (Eds), Catálogo de las Plantas Vasculares del Cono Sur, (Argentina, Sur de Brasil, Chile, Paraguay y Uruguay). Monogr Syst Bot Missouri Bot Garden 107: 26-31.

PRADO J. 2004. Criptógamos do Parque Estadual das Fontes do Ipiranga, São Paulo, SP. Pteridophyta: 5. Dennstaedtiaceae. Hoehnea 31(1): 11-22.

Punt W, Blackmore S, Nilsson S And Le ThOMAS A. 1994. Glossary of pollen and spore terminology. Utrecht: LPP contribution Ser, $71 \mathrm{p}$.

PUNT W, HOEN PP, BLACKMORE S AND LE THOMAS A. 2007. Glossary of pollen and spore terminology. Ver Palaeobot Palyno 143(1): 1-81.

RAMÍREZ-TREJO MDR, PÉREZ-GARCÍA B, MENDOZARUIZ A, VALDEZ-AVILA R AND ESPINOSA-MATÍAS S. 2013. Observations of the spore, gametophyte and young sporophyte of Pteridiumcaudatum (L.) Maxon using scanning electron microscopy. Micron 45: 37-44.

ROWLEY JR. 1981. Pollen wall characters with emphasis upon applicability. Nord J Bot 1(3): 357-380.

ROWLEY JR. 1987. Plasmodesmata-like processes of tapetal cells. Cellule 74: 227-242.

ROWLEY JR. 1995. Are the endexines of pteridophytes, gymnosperms and angiosperms structurally equivalent? Rev Palaeobot Palyno 85(1): 13-34.

ROWLEY JR AND NILSSON S. 1972. Structural stabilization for electron microscopy of pollen from herbarium specimens. Grana 12(1): 23-30.

ROWLEY JR, SKVARLA JJ AND El-GHAZALY G. 2003. Transfer of material through the microspore exine from the loculus into the cytoplasm. Can J Bot 81(11): 1070-1082.

SCHWARTSBURD PB. 2010. Lista de Espécies da Flora do Brasil. Jardim Botânico do Rio de Janeiro. Available from http://floradobrasil.jbrj.gov.br/jabot/listaBrasil/ ConsultaPublicaUC/BemVindoConsultaPublicaConsultar. do; accessed 22 April 2014.

SEHNEM A. 1972. Pteridáceas. In: Reitz R (Ed), Flora Ilustrada Catarinense I (PTER). Itajaí: Herbario Barbosa Rodriguez, $244 \mathrm{p}$.

SELling OH. 1946. Studies in Hawaiian Pollen Statistics. Part I: The spores of the Hawaiian Pteridophytes. Special Publicación 37. Honolulu: Publisher by The Museum, 87 p.

SMith AR, PRYER KM, SchuettPelz E, Korall P, SCHNEIDER H AND WOLF PG. 2006. A classification for extant ferns. Taxon 55: 705-731.

SOEPADMO E AND KHOO EE. 1977. Spore morphology of Malayan Dennstaedtiaceae sensu Holttum. Gard Bull Singapore 30: 85-95.
TARDIEU-BLOT ML. 1966. Sur les spores de fougéres malgaches: Filicales (Fin) Marattiales, Ophioglossales. Polen et spores 8(1): 75-122.

TAYLOR JA. 1990. The bracken problem: a global perspective. AIAS Occasional Publication 40: 3-19.

THOMSON JA. 2004. Towards a taxonomic revision of Pteridium (Dennstaedtiaceae). Telopea 10(4): 793-803.

Thomson JA. 2012. Taxonomic Status of Diploid Southern Hemisphere Brackens (Pteridium: Dennstaedtiaceae). Telopea 14: 43-48.

THOMSON JA AND ALONSO-AMELOT ME. 2002. Clarification of the taxonomic status and relationships of Pteridium caudatum (Dennstaedtiaceae) in Central and South America. Bot J Linn Soc 140(3): 237-248

ThOMSON JA, CHIKUni AC AND MCMASTER CS. 2005. The taxonomic status and relationships of bracken ferns (Pteridium: Dennstaedtiaceae) from sub Saharan Africa. Bot J Linn Soc 148(3): 311-321.

ThOMSOn JA, Mickel JT AND Mehltreter K. 2008. Taxonomic status and relationships of bracken ferns (Pteridium: Dennstaedtiaceae) of Laurasian affinity in Central and North America. Bot J Linn Soc 157(1): 1-17.

TRIANA-MORENO LA. 2012. Caracteres morfológicos en esporas de Polypodiaceae y su aplicación en la reconstrucción filogenética. Boletín Científico. Centro de Museos. Bol Cient Mus Hist Nat 16(2): 53-59.

TRYON AF. 1986. Stasis, diversity and function in spores based on an electron microscope survey of the Pteridophyta. Linn Soc Symp Ser 12: 233-249.

TRYON AF AND LUGARDON B. 1991. Spores of the Pteridophyta: surface, wall structure, and diversity based on electron microscope studies. New York: SpringerVerlag, $648 \mathrm{p}$.

TRYON RM. 1941. A revision of the genus Pteridium. Rhodora 43: 1-31, 37-67.

TRYON RM AND TRYON AF. 1982. Ferns and allied plants with special reference to tropical America. New York: Springer-Verlag, $857 \mathrm{p}$.

VAN COTTHEM W. 1970. Comparative morphological study of the stomata in the Filicopsida. Bull Jard Bot Etat 40: 81-239.

WELMAN WG. 1970. The South African Fern Spores, Part VI. In: Van Zinderen Bakker SR (Ed), South African Pollen Grains and Spores. Cape Town: A. A. Balkema, 110 p.

WITTBORN J, RAO KV, EL-GHAZALY G AND ROWLEY JR. 1998. Nanoscale Similarities in the Substructure of the Exinesof Fagus Pollen Grains and Lycopodium Spores. Ann Bot-London 82(2): 141-145.

YAÑEZ A, MARQuez GJ, Morbelli MA. 2011. Análisis palinológico del género Dennstaedtia (Dennstaedtiaceae) de la Provincia de Misiones, Argentina. Bol Soc Argent Bot 48(Supl.): 265.

YAÑEZ A, MARQueZ GJ AND MORBElli MA. 2013. Palinología de las Dennstaedtiaceae de la Provincia Fitogeográfica Paranaense: Taxones que producen esporas monoletes. Bol Soc Argent Bot 46(Supl.): 244. 